\title{
1. The special nature of banks and its challenges for competition policy \\ Ioannis Kokkoris
}

Effective competition and consumer protection are all the more important when the economy is under pressure. And we need an efficient banking system and efficient financial markets now more than ever in order to increase productivity and growth in the UK economy. ${ }^{1}$

\section{INTRODUCTION}

Banks have a unique standing in the economy, and the structure of their balance sheets has led to their being given greater protection than other industries. ${ }^{2}$ They are regarded as more vulnerable to instability than other firms as they provide liquidity and are involved in inter-bank lending markets and the payment system. ${ }^{3}$

The submission by the United States to a report published by the Organisation for Economic Co-operation and Development (OECD) entitled 'Competition and the Financial Markets's states that since September 2008 financial markets in the US and around the world have experienced significant turmoil. In 2008, 25 banks in the US had failed and, at the end of the third quarter of 2008, 171 banks were identified as 'troubled'. ${ }^{5}$ Bank failure carries the risk of systemic effects. As the OECD argues, the loss of confidence in one major financial institution during a financial crisis can snowball into a loss of confidence in the entire market because the inability of one bank to meet its obligations can drive other, otherwise healthy, banks into insolvency. ${ }^{6}$ The collapse of confidence can in turn cause liquidity to disappear, and thus remove an essential element for the proper functioning of the banking system, almost inducing systemic collapse.

Due to the systemic nature of banks, governments try to avert a crisis that can affect the whole banking sector by ensuring that banks which are 'too-big-to-fail' remain sustainable. Such intervention has a distortive effect on competition, as it prevents 'self-correction'

1 Philip Collins, 'Making Financial Markets Work Well for Consumers', speech to Cass Business School, 30 March 2010.

2 Charles Goodhart, The Evolution of Central Banks (MIT Press 1988) p. 61; and George Kaufman, 'Bank Failures, Systemic Risk, and Bank Regulation' (1996) 16(1) Cato Journal 17-45, 39 (Kaufman 1996).

3 Elena Carletti, Philip Hartmann and Giancarlo Spagnolo, 'Bank Mergers, Competition and Liquidity', ECB Working Paper 292, November 2003.

4 Contribution of the United States to OECD Report, 'Competition and Financial Markets 2009', DAF/COMP(2009)11/ADD1, 215.

5 Joe Adler, 'Success with Failures' (2008) American Banker, at 1.

6 OECD, Competition and Financial Markets, Report, 2009 (OECD 2009 Report). 


\section{Research handbook on State aid in the banking sector}

of the market. ${ }^{7}$ State aid can enable inefficient banks to remain in operation, contrary to the usual corporate environment where inefficient companies would exit the market. State aid can prolong the crisis by allowing the preservation of large inefficient banks.

Competition policy should generally be kept separate from policies that relate to considerations of the 'too-big-to-fail' doctrine. The approval of State aid or bank mergers should relate strictly to competition principles without any consideration of the risk incurred by the creation or maintenance of a 'too-big-to-fail' bank. However, in periods of crisis, competition policy may have to be lenient towards such State aid measures or mergers that sustain such banks. Taking account of the 'too-big-to-fail' doctrine in State aid and merger assessment during non-crisis periods will relegate competition policy to a mere tool of financial regulation. On the other hand, being pragmatic in State aid and merger policy during crisis periods contributes to the viability of financial markets.

This chapter will discuss the special nature of the banking sector and its implications for competition policy. It will analyse the particular features of the sector that differentiate it from other sectors of the economy, and will then assess the impact of the State aid regime on the banking sector during the recent financial crisis and its aftermath.

\section{THE NATURE OF THE BANKING SECTOR}

It would be a serious error to exempt the banking sector from the competition regime altogether or to ascribe these recent disastrous events to an excess of competition. This has not yet been said explicitly on a wide scale but it is a short step from calling these events a 'failure of the market' to blaming them on 'too much competition'. 8

\section{(a) The Systemic Nature of the Banking Sector}

During times of financial crisis, ensuring financial stability is accorded greater importance than the efficiency gains pursued by competition policy. During the recent crisis a number of measures were adopted and implemented, including various State aid measures and mergers which were approved in the interests of financial stability even though they had a negative impact on competition. ${ }^{9}$ These measures led to the enhancement of

\footnotetext{
7 Mark Flannery and Sorin Sorescu, 'Evidence of Bank Market Discipline in Subordinated Debenture Yields' (1996) 51(4) Journal of Finance 1347.

8 Peter Freeman, President of the UK Competition Commission, 'We Are Here in a Very Melancholy Situation: Financial Crisis and Competition Policy', speech to David Hume Institute, 3 November 2009.

9 See e.g. UK Office of Fair Trading (OFT), Lloyds/HBOS [2008] ME/3862/08. The Lloyds/ $H B O S$ merger is a clear example of the direct and unprecedented intervention of the UK government in the assessment of mergers in the middle of a financial crisis. Prior to this merger, the financial sector was strictly within the remit of the OFT and the UK Competition Commission (CC). In this case, however, the UK government intervened and allowed the merger despite the fact that it was capable of giving rise to competition concerns. The merger was cleared on the basis of the bad financial situation of HBOS and the disadvantages that a failure of the bank would entail in terms of consumer confidence. In fact, the government enabled the Secretary of State to decide on the merger and suspend competition rules in order to maintain general financial stability. See
} 
moral hazard, and adverse effects in the competitiveness of the banking market both within and between Member States.

The banking sector has features and performs functions that are special and have a significant impact on the real economy: it channels resources and facilitates risk management. The banking sector is pivotal for economic growth by providing much needed liquidity on the one hand, and holding deposits on the other. Banks also provide the means for financial transactions. A competitive banking market will provide such finance.

At the same time banks are inherently unstable, due to their exposure to systemic risk and contagion from other banks through their interconnected balance sheets and system of payments. ${ }^{10}$ For these reasons, the banking sector has been subject to tight regulation. Some of the basic goals of financial regulation are consumer/investor protection, financial stability and market efficiency. ${ }^{11}$ By contrast, competition aims to enhance consumer welfare. Competition and financial regulation are both aimed at ensuring that financial markets will work effectively and financial stability will be ensured. ${ }^{12}$

As Kaufman notes, banks are considered fragile because they are susceptible to contagion for three primary reasons: (1) low capital-to-assets ratio (high leverage with little capital to cover losses); (2) low cash-to-assets ratio (fractional reserve banking that requires sales of earning assets to meet deposit obligations); and (3) high-demand debt and short-term debt-to-total debt ratio (maturity mismatch of assets and liabilities, which is the cause of bank runs). According to Kaufman, the primary reason for the special treatment of banks is their asset-liability mismatch. ${ }^{13}$

Psaroudakis discusses some of the main reasons for the systemic nature of the banking sector. ${ }^{14}$ A bank's liquidity problems may spread easily through the inter-bank market and, as banks borrow from depositors and lend with long-term maturity, they depend on the confidence placed in them by the public. Psaroudakis adds that depositors cannot assess the quality of the bank, and a crisis that affects one can easily spread to the whole sector. As a result of the importance and role of the banking sector, one bank failure can lead to serious disturbance across the whole economy.

Turning to the debate on the impact of bank competitiveness on bank stability, Acharya et al. argue that while a concentrated banking system may be easier to monitor and banks may be more diversified, at the same time banks that are 'too-big-to-fail' might take more risks knowing they will be guaranteed by governments. ${ }^{15}$ Market discipline has been

further Ioannis Kokkoris and Rodrigo Olivares-Caminal, Antitrust Law Amidst Financial Crises (CUP 2010) (Kokkoris and Olivares-Caminal 2010).

10 Jakob De Haan, Sander Oosterloo and Dirk Schoenmaker, Financial Markets and Institutions, A European Perspective ( $2^{\text {nd }}$ edn, CUP 2012).

11 Ibid.

12 Ibid.

13 Kaufman 1996, 39.

14 George Psaroudakis, 'State Aids, Central Banks and the Financial Crisis' (2012) 9(2) European Company and Financial Law Review 194 (Psaroudakis 2012).

15 Viral Acharya, Denis Gromb and Tanju Yorulmazer, 'Imperfect Competition in the Interbank Market for Liquidity as a Rationale for Central Banking' [2010] Working paper FIN-09031; Xavier Vives, 'Competition Policy in Banking' (2011) 27(3) Oxford Review of Economic Policy 479 (Vives 2011). 
deemed ineffective because of the blanket insurance offered by 'too-big-to-fail' policies. There have been theoretical and empirical studies that support the notion that there is a trade-off between economic efficiency and stability in the banking system. ${ }^{16}$ Improvement in bank regulation rather than enhancing competition among banks has been proposed as the ideal scenario for mitigating any risks bank competition has for financial stability. ${ }^{17}$

Beck et al. claim that systemic crises are less likely in concentrated banking and that fewer regulatory restrictions are associated with less systemic fragility; competition is therefore not harmful for stability but could instead be a contributory factor to financial stability. ${ }^{18}$ Cejnar and Duke argue that the monopoly rents that come with market power can constitute a buffer against adverse shocks, and that banks with market power are therefore less likely to take excessive risks because of the opportunity cost of failure. ${ }^{19}$ The systemic nature of bank failure favours a policy that relegates competition policy. Governments are likely to be more concerned about bank failure when banking markets are concentrated, because in concentrated markets the consequences of any single bank failure are more significant. ${ }^{20}$

It has been argued that the banking sector's critical functions would be jeopardized if banks were allowed to compete freely against one another for depositors and borrowers, because this would increase risk taking and thus moral hazard. ${ }^{21}$ Concentrated banking markets have been deemed safer in terms of financial stability. Consolidation is increasing together with sector restructuring. The number of banks declined from 1997 to 2007 in both the US (by 22 per cent) and Europe (EU-15 by 29 per cent). The 1990s saw a decline in the number of banks in several OECD countries. The reasons behind the consolidation of banking activity include the relaxation of geographic restrictions of bank operations and the elimination of structural regulations that prevented bank mergers from taking place. $^{22}$

As Vives argues, an increase in the level of competition will tend to increase risk-taking incentives and the probability of bank failure, but this tendency may be mitigated by appropriate regulation and supervision. ${ }^{23}$ However, an OECD study presented empirical evidence showing that increasing competition in the banking sector helped to prevent financial stability risks and argued that there were quite a few oligopolistic banking markets that faced significant systemic risks during the crisis. ${ }^{24}$ Other studies concluded

16 Michael Keeley, 'Deposit Insurance, Risk and Market Power in Banking' (1990) 80 American Economic Review 1183.

17 OECD 2009 Report, Key Findings.

18 Thorsten Beck, Asli Demirgüç-Kunt and Ross Levine, 'Bank Concentration and Crises' (2006) 30(5) Journal of Banking and Finance 1581.

19 Leela Cejnar and Alan Duke, 'Competition Policy and the Banking Sector: The Need for Greater International Co-operation’ (2013) 34(11) ECLR 583.

20 Ibid.

21 Ilias Kapsis, 'Competition Law and Policy for the EU Banking Sector in a Period of Increased Economic Uncertainty' (2012) 54(4) IJLM 284 (Kapsis 2012).

22 Stephen A. Rhoades, 'Competition and Bank Mergers: Directions for Analysis from Available Evidence' (1996) The Antitrust Bulletin 339; Stephen A. Rhoades, 'Research on IO Topics in Banking: An Introduction and Overview' (1997) 12 Review of Industrial Organisation, 1.

23 Vives 2011.

24 OECD 2009 Report, Key Findings. 
that market power made financial markets less stable as it created an incentive to engage in riskier behaviour. ${ }^{25}$

\section{(b) The 'Too-Big-to-Fail' Nature of the Banking Sector}

As mentioned above, certain banks expect that governments will not allow their failure and this can increase reckless risk taking or delay efforts to act vigorously in the markets. Studies point to a number of reasons for the potential failure of a bank. It could be a failure of regulation, the monetary policies of central banks or inadequate supervision that was responsible for the financial crisis, rather than the degree of competition. ${ }^{26}$ Due to the importance of the 'too-big-to-fail' nature of some banks, central banks have long struggled to avoid allowing the 'too-big-to-fail' doctrine to induce moral hazard and have attempted to avoid any definition of whether an institution falls into that category. As Sir Callum McCarthy, former Chair of the UK's Financial Services Authority, argues:

the general view is that there is a real problem with the 'too-big-to-fail' concept and that it would be perfectly rational for depositors and counterparties to trade preferentially with larger firms, thus squeezing out the smaller ones. Preventing that would be a real issue in terms of competition policy. ${ }^{27}$

Molyneux argues ${ }^{28}$ that central banks should always continue to maintain a policy of ambiguity associated with the provision of support for troubled banks, strongly rejecting making explicit guarantees ex ante because regulators will wish to avoid weakening market discipline (moral hazard) and they will not want to commit themselves to future courses of action which they might subsequently prefer not to take. The 'too-big-to-fail' doctrine should only be used in exceptional circumstances because its result may be that the use of the medicine is worse than the illness. The knowledge that the authorities will allow a bank, even a big bank, to fail is an important mechanism of market discipline. ${ }^{29}$

25 See e.g. Michael Keeley, 'Deposit Insurance, Risk and Market Power in Banking' (1990) 80 American Economic Review 1183.

26 Ilias Kapsis, 'The Impact of the Recent Financial Crisis on EU Competition Policy for the Banking Sector' (2010) 9(3) JITLP 256; and Stephen Maes and Kamil Kiljanski, 'Competition and the Financial Markets: Financial Sector Conditions and Competition Policy' (2009) Competition Policy Newsletter 2009/1, 3; OECD 2009 Report, Key Findings; Adrian Blundell-Wignal and Paul Atkinson, 'Origins of the Financial Crisis and Requirements for Reform' (2009) 20 Journal of Asian Economics 536.

27 Presentation to the OECD, Summary Record of the Discussion on Competition and Financial Markets, DAF/COMP/M(2009)1/ANN5, 10 April 2009, 'Roundtable 4 on Going Forward: Adaptation of Competition Rules, Processes and Institutions to Current Financial Sector Issues' <www.oecd.org> accessed 27 April 2016.

28 Philip Molyneux, 'Banking Crises and the Macro-economic Context', in Rosa M. Lastra and Henry N. Schiffman (eds), Bank Failures and Bank Insolvency Law in Economies in Transition (London: Kluwer Law International, 1999) (Molyneux 1999), at 5-6.

29 Discretion by the central bank authorities creates uncertainty. Therefore, the 'great task' of central banks has to be performed prior to the crises. To achieve this, strict supervision of the banks is required, as well as an improvement in the accounting standards to reflect the 'real' situation of the banks. Financial disclosure is increasingly favoured by banks, their supervisors and international organizations as an instrument promoting transparency without adding undue regulatory burdens or creating competitive distortions for banks vis-à-vis other financial institutions. Rosa M. Lastra, 'Central Banking and Banking Regulation' (1996) FMG 123. 
Businesses have greater incentive to engage in risky and likely reckless practices if they believe they will be rescued, and this mitigates their competitive dynamism. Maintaining a vague government policy in relation to banks that will be rescued ensures sufficient incentive for risk-averse behaviour of market participants. ${ }^{30}$

Specifically for the financial industry, the 'too-big-to-fail' concept has been at the heart of the debate during the recent crisis and is a major factor in determining the counterfactual. The doctrine is understood to mean that, if a bank is big enough, it will receive financial assistance to the extent necessary to keep it from failing. ${ }^{31}$ It implies that all deposit obligations will be met by some form of government pledge or guarantee regardless of whether a deposit insurance scheme is actually in place. ${ }^{32}$ In other words, taxpayers will bail out the failing bank. ${ }^{33}$ As a result of the crisis, the 'too-big-to-fail' doctrine has evolved, and has even been expanded to include 'too-interconnected-to-fail', 'toocomplex-to-fail' and 'too-global-to-fail'. ${ }^{34}$

If some banks are deemed 'too-big-to-fail' this suggests that those banks are safer than others. ${ }^{35}$ This distorts the market because large banks have an ex ante competitive advantage over smaller banks which are not considered 'too-big-to-fail'. In this respect it is worth noting that there are no set criteria to measure whether a bank is 'too-big-to-fail', which gives governmental officials a degree of discretion. In certain circumstances the social cost of rescuing the relevant institutions will be less than the ruinous cascade of knock-on effects that might surge through the financial sector. This is the state of being 'too-big-tofail', which both the FTC and DOJ have identified as an outcome that antitrust law could and should prevent. ${ }^{36}$ If competition authorities wish to prevent companies from becoming 'too-big-to-fail', they may have to put less emphasis on efficiencies arising from mergers. The change in focus of competition authorities is likely to harm consumer welfare, as efficiencies aimed at its enhancement will not be allowed to materialize. Such an approach may also discourage firms from investing to achieve such efficiencies in the first place.

\section{(c) Competition Policy and the Banking Sector}

Some argue that the banking sector should not be considered as having 'natural monopoly' characteristics and that consequently there is little scope for control of monopoly power. ${ }^{37}$ Prudential regulation was given the prime spot in decision-making, emphasizing

\footnotetext{
30 Psaroudakis 2012.

31 Molyneux 1999, 5-6.

32 Some illustrative examples in this sense are: Continental Illinois in the USA (1984), Banesto in Spain (1993), Banco di Napoli in Italy (1996), Credit Lyonnais in France (1997).

33 See Molyneux 1999, 6.

34 See Michael D. Knight, 'Mitigating Moral Hazard in Dealing with Problem Financial Institutions: Too Big To Fail? Too Complex To Fail? Too Interconnected To Fail?' in John Raymond LaBrosse, Rodrigo Olivares-Caminal and Dalvinder Singh (eds), Financial Crisis Management and Bank Resolution (Informa 2009), 257.

35 See Molyneux 1999, 4.

36 Interview with Thomas Rosch, Commissioner, Federal Trade Commission (2009) 23 Antitrust 32, 41.

37 Charles Goodhart, 'The Emerging New Architecture of Financial Regulation' (2011) CFS Working Paper 2011/12, Center for Financial Studies; Rob Nicholls and Justin O’Brien, 'Hanging
} 
that financial stability was of paramount and insurmountable importance, and placing competition policy in a subordinate role. The urgency and potential disaster was too great and the need to act to save a sector on which other industries relied meant that competition policy was accorded less weight than systemic stability.

Competition aims to enhance consumer welfare. Competition policy normally takes priority over State activities, and over conduct that harms competition. It favours rivalry, but the recent financial crisis gave prominence to the view that the loss of competitive rivalry was not significant under existing economic conditions. During the economic crisis most governments intervened in markets to support their banking industry on the basis that most of the players were 'too-big-to-fail', or that the sector as a whole was too important to be weakened. Few governments allowed their intervention to be disciplined in any way by competition policy considerations. ${ }^{38}$ This is even true of the European Union, which is unique in actually having the power to control such interventions through its regulation of aid from states to private companies.

The benefits of competition in the banking sector are manifested in the lower borrowing rates and lower collateral available to customers when banks intensify their competition. The OECD mentioned that there is a negative relationship between an increase in the level of concentration and savings deposit rates, and a positive relationship between an increase in concentration and an increase in interest rates. ${ }^{39}$

A report by the International Competition Network (ICN) on antitrust enforcement in regulated sectors ${ }^{40}$ states that it is:

[. . . possible to distinguish two mechanisms by which the failure of one bank could lead to the failure of other banks or other non-bank firms:

(i) the failure of one bank leading to a decline in the value of the assets sufficient to induce the failure of another bank ('consequent failure'); and

(ii) the failure of one bank leading to the failure of another fully solvent bank, through some contagion mechanism ('contagion failure').

The ICN Annual Conference in Bonn ${ }^{41}$ recommended a number of best practice guidelines to ensure a competitive and efficient banking industry through liberalization, effective regulatory institutions, efficient application of competition law and competition advocacy initiatives. The latter initiatives should incorporate equal treatment of financial institutions by competition authorities, as well as the elimination of information asymmetries between banks and customers. ${ }^{42}$

Together or Hanging Separately: Is Competition Law in the Process of Eclipsing Financial Regulation?' (2014) 8(2) LFMR 178.

38 Member States primarily injected capital into banks and raised deposit guarantees to reassure the public and prevent runs on banks (UK - NN 41/2008, Ireland - NN 48/2008, Denmark - NN 51/2008, Sweden and Spain - N 337/2009).

39 OECD Policy Roundtable on 'Competition and Regulation in Retail Banking', 2006.

40 ICN, 'Antitrust Enforcement in Regulated Sectors Subgroup 1: An Increasing Role for Competition in the Regulation of Banks', Bonn, June 2005.

41 Ibid.

42 Jonathan R. Macey and Geoffrey P. Miller, 'Deposit Insurance, the Implicit Regulatory Contract, and the Mismatch in the Term Structure of Banks' Assets and Liabilities' (1995) 12(1) Yale Journal on Regulation. 
On the basis of the ICN's report, governments should promote an open, competitive, banking market and ensure that there is effective separation between the enforcement of prudential regulation and competition laws.

Optimal regulation needs a combination of risk-based insurance for deposits that internalizes the social cost of bank failures and mitigates their appetite for risk. Regulation can reduce the adverse consequences of the trade-off between competition and financial stability. The view that competition is negative for banking stability, since it generally causes instability, can be dismissed. ${ }^{43}$ Competition per se does not need to create instability. As illustrated by Matutes and Vives, bank vulnerability to bank runs can also emerge independently of competition and can thus occur in any market structure. ${ }^{44}$ Competition enforcement is not responsible for fragility in banking, but competition policy should be pragmatic in acknowledging the uniqueness of banks.

Carletti et al. address more directly the effects of bank consolidation on the competition and liquidity risk in the banking sector. ${ }^{45}$ Their analysis is not conclusive as regards the conflicts between competition and regulatory authorities in competition enforcement. They add that the negative correlation between competition in the banking sector and financial stability is not proven. ${ }^{46}$ They also note that their analysis shows no concrete relationship between competition and stability in the banking system and whether competitive banking markets harm the stability of the banking markets. The theories behind the causes of bank runs and the causes of systemic risk disregard the various bank market structures for the stability of the sector, and theories based on the idea of 'charter value' argue that market power mitigates bank risk taking, since foregone future profits in the case of bankruptcy are higher. ${ }^{47}$

After the above discussion of the special nature of the banking sector, the next section will discuss the treatment of banks during the recent financial crisis in an attempt to assess whether that specificity was taken into account during that period.

\section{THE TREATMENT OF BANKS DURING THE FINANCIAL CRISIS}

This section will briefly discuss the State aid regime and its importance for the stability and sustainability of the banking sector during the recent crisis. The aim is not to provide a full and detailed account but to provide a coherent and succinct summary; later chapters in this volume will address these issues in greater detail.

Under the Treaty on the Functioning of the European Union (TFEU), the European Commission (Commission) is given the competence to determine whether or not the noti-

43 Elena Carletti and Philip Hartmann, 'Competition and Stability: What's Special about Banking?' (2002) Working Paper 146.

44 Carmen Matutes and Xavier Vives, 'Competition for Deposits, Fragility and Insurance' (1996) 5(2) Journal of Financial Intermediation 184.

45 Elena Carletti, Philip Hartmann and Giancarlo Spagnolo, 'Bank Mergers, Competition and Financial Stability' (2002) Mannheim University and ECB < http://www.bis.org/cgfs/hartmann. pdf $>$ accessed 27 April 2016.

46 Ibid.

47 Ibid. 
fied aid measure constitutes State aid within the meaning of Article 107(1). This assumes that Member States are able to assess what constitutes State aid under the TFEU. Article 107 identifies the cumulative criteria that must be fulfilled for an action to constitute State aid. ${ }^{48}$ According to the text of Article 107, any aid granted by a Member State or through State resources, which distorts or threatens to distort competition by favouring certain undertakings or the production of certain goods, is incompatible with the common market. Article 107 also outlines acceptable forms of aid.

Therefore, State aid control guarantees a level playing field for all firms operating within the internal market. In Stardust Marine the Court of Justice of the European Union identified a list of factors, including: the degree to which the requirements or guidelines of public authorities influenced the decision taken; the extent of integration of the public entity into public administration structures; the nature of the undertaking's activities and their actual exercise in the market under normal market conditions; the legal status of the undertaking, any other indicators showing the likelihood or not of State involvement; all in light of the scope, content and conditions of the measure. ${ }^{49}$

In order to fall within the remit of Article 107(1), aid needs to be 'granted by the state or through state resources'. The first question is therefore whether the measure can be imputed to the State. The second issue is whether the aid derived from State resources. In the Sloman Neptun case, the Court of Justice argued that the wording of Article 107(1) was aimed at 'bringing within the definition of aid not only aid granted directly by the state, but also aid granted by public or private bodies designated or established by the state'. ${ }^{50}$

Article 107(2) and (3) provide for a set of mandatory and discretionary exemptions respectively, the correct application of which is entrusted to the Commission. The general principle of incompatibility under Article 107(1) calls for a restrictive interpretation of the derogatory provisions. The burden of proof lies with the Member States to show that the proposed aid meets the necessary conditions for its approval. ${ }^{51}$ According to Article 107(2), aid satisfying the conditions is automatically compatible with the internal market; it does not accord the Commission any discretion. The automatic exemption from the general ban on State aid does not, however, exonerate Member States from their duty to notify the Commission. Article 107(2)(a) exempts 'aid having a social character, granted to individual consumers, provided that such aid is granted without discrimination related to the origin of the products concerned'. An example of this type of social aid is aid in the form of discounted airfares for island residents. ${ }^{52}$ Article 107(2)(b) renders compatible with the common market aid intended to 'make good the damage' caused by natural disasters or exceptional circumstances; in other words it aims to neutralize the damage and loss of profit suffered, not to over-compensate the recipients. ${ }^{53}$

48 See e.g. Art. 1(a) of the Procedural Regulation 659/1999 which states that 'aid shall mean any measure fulfilling all the criteria laid down in Article 92(1) (now 107(1) EC) of the Treaty'.

49 See Case C-482/99 Stardust Marine [2002] ECR I-4397.

50 Joined cases C-72/91 and C-73/91 Sloman Neptun Schiffahrts AG v Seebetriebstrat Bodo Ziesemer der Sloman Neptun Schiffahrts AG [1993] ECR I-887, paras 19 and 21.

51 See Case C-364/90 Italy v Commission [1993] ECR I-2097.

52 See e.g. the recent Commission approval of social aid for air travel between mainland Portugal and the Autonomous Region of Madeira, Commission Press Release IP/07/1900, 11 December 2007.

53 See Case C-73/03 Spain v Commission [2004] ECR I-000. 


\section{Research handbook on State aid in the banking sector}

While under Article 107(2) the aid, 'shall be compatible with the Internal Market', under Article 107(3) the Commission enjoys a wide measure of discretion as to its decision on whether the aid 'can be declared compatible'. Under the first section of Article 107(3)(b) the execution of an important project of common European interest may entail the granting of aid. In this case, aid will be granted to promote the project. 'An important project of common European interest' is a broad concept which could extend to projects that also benefit, or are initiated by, non-EU countries. The derogation might apply to projects carried out in a single Member State which, while not necessarily supported by several Member States, can still be deemed of common interest.

A further category of potentially compatible aid under this sub-paragraph concerns aid to remedy a serious disturbance in the economy of a Member State. The 'serious disturbance' must affect the whole of the economy of that Member State, or at least several sectors rather than one region or sector; in this case the regional or sectoral exemptions respectively may come into play. Consequently, the most appropriate remedial instrument under these circumstances would be an aid scheme. Individual aid to just one company could arguably be justified if the latter's collapse was likely to induce a negative domino effect across the whole of a Member State's economy or across several sectors. In such an extreme case, aid could be authorized to both the firm in difficulty and those affected by its situation. ${ }^{54}$ The rationale behind this derogation is strictly absorption of the shocks caused by serious economic turmoil and the aid released must by no means place the recipient undertakings in a stronger position than that held prior to the disturbance.

During the recent financial crisis, the Commission initially implemented its usual State aid provisions to allow national aid measures in favour of banks on the basis of it being 'aid to remedy a serious disturbance in the economy of a Member State'. ${ }^{55}$ The EU rubber-stamped almost all of the interventions made by Member States to support their domestic banking industry. ${ }^{56}$ During the crisis the Commission, pursuant to the 2008 Banking Communication, ${ }^{57}$ decided that it would temporarily approve necessary measures taken by Member States to safeguard the stability of the financial system, including rescue measures and recapitalization schemes.

During the crisis, the Commission issued a number of Communications related to

54 See Brian Quigley and Anthony Collins, EC State Aid Law and Policy (Hart Publishing 2003).

55 TFEU, 107(3)(b).

56 An indication of this is that, until 16 December 2009, of the 81 decisions adopted by the Commission only six were conditional decisions after a formal investigation procedure. Between 2002 and 2007, the amount of State aid to industry and services decreased annually on average by 2 per cent (€65 billion). The financial crisis led to an explosion of State aid. Total State aid (excluding railways) granted by the Member States amounted to $€ 279.6$ billion in 2008 . The level of State aid almost quintupled in 2008 compared to 2007 - almost exclusively as a result of crisis aid to the financial sector. Between October 2008 and October 2009, the Commission approved measures amounting to around $€ 3,632$ billion. See Kokkoris and Olivares-Caminal 2010.

57 The 2008 Communication has been replaced by the Communication from the Commission on the application, from 1 August 2013, of State aid rules to support measures in favour of banks in the context of the financial crisis (Banking Communication) [2013] OJ C216/1. 
the assessment of State aid, ${ }^{58}$ which have been criticized for being too permissive. The Recapitalization Communication incorporated measures to restore financial stability, ensure lending to real economy, limit the risks of banks becoming insolvent, remunerate close to market prices and provide incentives for State capital redemption. The objective was restoration of the financial stability of the banks. As a result of a recapitalization scheme or measure, the Commission argued that distortions of competition could arise from banks obtaining an undue competitive advantage over banks in other Member States as well as from putting banks without recourse to public funding in a significantly less competitive position.

In addition, schemes targeting all banks within a Member State without any degree of differentiation according to risk profiles may give an advantage to distressed or less performing banks. ${ }^{59}$ In the Impaired Assets Communication, the Commission incorporated guidelines for the treatment of impaired assets, addressed transparency and disclosure of impairments, addressed valuation of impaired assets, the burden sharing between the State, shareholders and creditors and provided incentives to participate in asset relief programs. ${ }^{60}$

Furthermore, the Banking Communication incorporated guidelines for State aid in the banking sector in the financial crisis, which focused on guarantee schemes, addressed non-discriminatory access, ensured appropriate private sector contribution and established appropriate follow-up (viability plan/restructuring plan). Pursuant to the Banking Communication, in order to avoid undue distortion of competition, Member States should include a combination of behavioural constraints or appropriate provisions enforcing behavioural constraints to ensure that the beneficiary did not engage in aggressive expansion. Another instrument for avoiding distortions of competition were adjustment measures for the sector as a whole and the restructuring or liquidation of individual beneficiaries. These principles required that restructuring aid lead to the restoration of viability of the undertaking in the longer term without State aid. They also required restructuring aid to be accompanied, to the extent possible, by adequate burden sharing and by measures to minimize distortions of competition. ${ }^{61}$

The Restructuring Communication incorporated guidelines for the restructuring of banks which addressed the transparency and disclosure of impairment, provided for

58 Communication from the Commission on the application of State aid rules to measures taken in relation to financial institutions in the context of the current global financial crisis [2008] OJ C270/8 (the First Banking Communication); Communication from the Commission on the recapitalisation of financial institutions in the current financial crisis: limitation of aid to the minimum necessary and safeguards against undue distortions of competition [2009] OJ C10/2 (the Recapitalization Communication); Communication from the Commission on the treatment of impaired assets in the Community banking sector [2009] OJ C72/1 (the Impaired Assets Communication); Communication from the Commission on the return to viability and the assessment of restructuring measures in the financial sector in the current crisis under the State aid rules [2009] OJ C195/9 (the Restructuring Communication). In August 2013 the Commission published the Banking Communication.

59 Kokkoris and Olivares-Caminal 2010.

60 Ioannnis Kokkoris, 'State Aid Law v Single Resolution Mechanism: David v Goliath or Vice Versa?' (2013) 10 International Corporate Rescue 6.

61 Ibid. 
the restoration of long-term viability, ensured adequate burden sharing (limitation of restructuring costs, significant own contribution), incorporated measures to minimize distortion of competition, included structural and behavioural remedies and provided for regular monitoring. Banks which benefited from State aid could have been required to divest subsidiaries or branches, portfolios of customers or business units or to limit their expansion in certain business or geographical areas. The Commission emphasized that State aid could not be used to fund anti-competitive behaviour such as acquisition of competing businesses or offering terms which could not be matched by competitors who did not receive aid. ${ }^{62}$

As Soltesz and Kockritz argue, in granting approval for State aid measures during the crisis, the Commission required adequate remuneration for the aid, a ban on dividend payments to shareholders over a certain period of time, and that banks benefiting from the aid undertook only to pay interest and coupons on hybrid instruments. ${ }^{63,}{ }^{64}$ In relation to compensatory measures, the Commission emphasized the need for a reduction of the banks' post-restructuring business activities, through divestments (such as the sale of participations and portfolios), reduction of business activities (reduction of branches, cessation of certain business activities and production areas, etc.) and greater balance sheet reductions compared to bank restructuring cases prior to the crisis. As Soltesz and Kockritz note, in banking cases before the crisis the Commission usually required a reduction in business volume of restructured banks of around one-third ${ }^{65}$ The authors provide examples of cases such as Bankgesellschaft Berlin (reduction by 30 per cent), ${ }^{66}$ Crédit Foncier de France (reduction by 25 per cent) ${ }^{67}$ Société Marseillaise de Crédit (by 20 per cent) ${ }^{68}$ Banco di Napoli (43 per cent) ${ }^{69}$ and Crédit Lyonnais (by approximately onethird). ${ }^{70}$ The Commission has also imposed a reduction of around 50 per cent in cases

62 Kokkoris and Olivares-Caminal 2010.

63 Silent contributions, profit and loss participation rights and certificates if they had a binding legal obligation to do so. No reserves were usually allowed to be liquidated to make such payments possible or to avoid a loss participation of such hybrid instruments. See further Commission Decision on Commerzbank (Case N 244/2009) [2009] OJ C147/4, 78; and Case C-43/2008 - West LB, Commission decision of 12 May 2009, Appendix to Art. 2 (1), 5.8. In addition, see Ulrich Soltesz and Christian Kockritz, 'From State aid Control to the Regulation of the European Banking System - DG COMP and the Restructuring of Banks' (2010) 6 European Competition Journal 285 (Solsetz and Kockritz, 2010); and Miguel Moura e Silva, 'Antitrust in Distress: Causes and Consequences of the Financial Crisis' (2013) 9(2) The Competition Law Review 119.

64 Solsetz and Kockritz 2010.

65 Ibid.

66 Case C-28/2002 - Bankgesellschaft Berlin AG, Commission Decision of 18 February 2004, [2005] OJ L116/1.

${ }_{67}$ Commission Decision 2001/89/EC conditionally approving aid granted by France to Crédit Foncier de France [2001] OJ L34/36.

68 Commission Decision 1999/508/EC conditionally approving aid granted by France to Société Marseillaise de Crédit [1999] OJ L198/1.

${ }_{69}$ Commission Decision 1999/288/EC giving conditional approval to the aid granted by Italy to Banco di Napoli [1999] OJ L116/36.

70 Commission Decision 98/490/EC concerning aid granted by France to the Crédit Lyonnais group [1998] OJ L221/28. 
such as $I K B$ (47.2 per cent), Commerzbank (45 per cent), ${ }^{71}$ Fortis (40 per cent), ${ }^{72}$ West LB (50 per cent) $)^{73}$ and BayernLB (at least 50 per cent). ${ }^{74}$

Soltezs and Kockritz add that if the amount of aid received by a bank is particularly high, or a bank had to ask repeatedly for substantial rescue aid measures, the Commission may require a balance sheet reduction of more than 50 per cent, and reflect cases where banks participate in asset relief programs or 'bad bank' schemes such as Northern Rock ${ }^{75}$ and Hypo Real Estate. ${ }^{76,77}$ As Soltesz argues, the commitments imposed by the Commission on State aid measures conflict to some extent with the main objectives of banking functions. ${ }^{78}$ A reduction of a bank's balance sheet achieved by reducing the loans granted will limit liquidity to the real economy. The imposition of significant divestments may lead to systemic effects and distortions of competition.

\section{THE BANKING COMMUNICATION}

The Banking Communication and the decisions on aid measures and schemes were adopted on the basis of Article 107(3)(b) TFEU, which exceptionally allows for aid to remedy a serious disturbance in the economy of a Member State. In this Communication the Commission states that financial stability has been the overarching objective of the Commission, and that it has tried to minimize the adverse impact on competition resulting from State aid provided to banks by Member States. In addition, the Banking Communication will be pivotal in ensuring a smooth transition from existing Commission initiatives aimed at ensuring financial stability to the future regime under the Single Resolution Mechanism ${ }^{79}$ (SRM)

71 Commission Press Release, State aid: Commission approves recapitalisation of Commerzbank, IP/09/711, 7 May 2009.

72 Commission Press Release, State aid: Commission clears State aid to rescue and restructure Fortis Bank and Fortis Bank Luxemburg, IP/08/1884, 3 December 2008.

73 Commission Press Release, State aid: Commission approves aid package for German bank WestLB, IP/09/741, 12 May 2009.

74 Commission Press Release, State aid: Commission opens in-depth investigation into aid package for German Landesbank BayernLB and its Austrian subsidiary Hypo Group Alpe Adria, IP/09/742, 12 May 2009.

75 Commission Decision in Case C-14/2008 on the State aid implemented by the United Kingdom for Northern Rock [2010] OJ L112/38; See Commission Press Release, State aid: Commission approves restructuring package for Northern Rock, IP/09/1600, 28 October 2009.

76 Commission Decision in Case C-15/2009 - Hypo Real Estate - Decision to extend proceedings and temporary approval of capital injections [2010] OJ C13/58, 68, stating that the proposed balance sheet reduction of around 70 per cent is sufficient in light of the 'extremely large amount of aid' that the bank has received.

77 Solsetz and Kockritz 2010.

78 Ibid.

79 Proposal for a Regulation of the European Parliament and the Council establishing uniform rules and a uniform procedure for the resolution of credit institutions and certain investment firms in the framework of a Single Resolution Mechanism and a Single Bank Resolution Fund and amending Regulation (EU) No 1093/2010 of the European Parliament and of the Council $\operatorname{COM}(2013) 520$ final (SRM Regulation). This proposal was adopted on 15 April 2014 and converted into Regulation on July 2014. The legal basis for the SRM is Article 114 TFEU, which allows for the adoption of measures for the approximation of the provisions laid down by law, regulation 
and Banking Recovery and Resolution Directive ${ }^{80}$ (BRRD). The aim is to achieve more decisive restructuring and stronger burden sharing for all banks in receipt of State aid.

The Commission has adapted the crisis rules for the banking sector in relation to public support during the crisis. ${ }^{81}$ Banks will be required to work out a restructuring/resolution plan before they can receive recapitalizations or asset protection measures. Public funding will be available only after bank shareholders and junior creditors contribute as a first resort.

The 2013 Banking Communication replaces the 2008 Banking Communication and supplements the remaining crisis rules. The new Communication introduces ex ante approval of a recapitalization plan. During the crisis, the Commission approved recapitalizations within a short timeframe and approved them as compatible with State aid rules on the basis of a restructuring plan that was submitted ex post. On the basis of the new regime banks need to submit a restructuring plan showing the long-term profitability of the bank before recapitalization measures are approved. If long-term profitability is not a viable option for the bank, a winding down plan needs to be submitted and approved. The new regime does allow for the flexibility of immediate intervention and temporary approval of a restructuring plan before a full assessment of the necessary measures, providing the competent supervisor confirms the urgency of action. In addition banks that have failed must introduce strict executive remuneration policies, and the Commission further clarified that financial stability remains the overarching objective of its assessment.

During the crisis, creditors were not required to contribute to rescuing credit institutions as there were no burden-sharing requirements. It quickly became common sense that Member States faced significant fiscal difficulties in intervening to ensure financial stability. In response, they introduced a new legal framework to enforce stricter ex ante burden sharing requirements. Some Member States introduced bail-in requirements of investors or creditors, while others refrained from such measures. This led to divergent funding costs between banks depending on the perceived likelihood of a bail-in. ${ }^{82}$ Thus the Commission emphasized in its Banking Communication that:

the minimum requirements for burden-sharing should be raised. Before granting any kind of restructuring aid, be it a recapitalization or impaired asset measure, to a bank all capital generating measures including the conversion of junior debt should be exhausted, provided that fundamental rights are respected and financial stability is not put at risk. ${ }^{83}$

or administrative action in Member States which have as their object the establishment and functioning of the internal market.

80 Directive 2014/59/EU of the European Parliament and of the Council of 15 May 2014 establishing a framework for the recovery and resolution of credit institutions and investment firms and amending Council Directive 82/891/EEC, and Directives 2001/24/EC, 2002/47/EC, 2004/25/EC, 2005/56/EC, 2007/36/EC, 2011/35/EU, 2012/30/EU and 2013/36/EU, and Regulations No 1093/2010 and (EU) No 648/2012, of the European Parliament and of the Council [2014] OJ L173/190.

81 Commission Press Release, State aid: Commission adapts crisis rules for banks, IP/13/672, 10 July 2013.

82 Banking Communication, para. 18.

83 Ibid., para. 19. 
Pursuant to this Communication, Member States are invited to submit a capital raising plan, before or as part of the submission of a restructuring plan containing capital raising measures by the bank and potential burden-sharing measures by the shareholders and subordinated creditors of the bank. Similarly, the BRRD requires Member States to ensure that each institution draws up and maintains recovery and resolution plans that will be assessed by the competent authorities to ensure they lead to recovery of the institution.

In the presence of market expectations that governments will support financially distressed banks, reckless risk taking is incentivized, which could undermine market stability and also finally hurt healthy banks. ${ }^{84}$ Recognizing the importance of preventing moral hazard, the Commission adds that aid should only be granted on terms which involve adequate burden sharing by existing investors and notes that:

Adequate burden-sharing will normally entail, after losses are first absorbed by equity, contribu-
tions by hybrid capital holders and subordinated debt holders. Hybrid capital and subordinated
debt holders must contribute to reducing the capital shortfall to the maximum extent. Such
contributions can take the form of either a conversion into Common Equity Tier 1 or a write-
down of the principal of the instruments. In any case, cash outflows from the beneficiary to the
holders of such securities must be prevented to the extent legally possible. The Commission will
not require contribution from senior debt holders (in particular from insured deposits, uninsured
deposits, bonds and all other senior debt) as a mandatory component of burden- sharing under
State aid rules whether by conversion into capital or by write-down of the instruments.

If the bank is still in need of a capital injection, then provided a restructuring plan is submitted, public recapitalization, impaired asset measures or a combination of the two can be provided. The Member State must obtain approval by the Commission before any recapitalization or impaired asset measures are taken. In cases of preserving financial stability though, as happened during the recent crisis, Member States can grant rescue aid on a temporary basis before a restructuring plan is approved. ${ }^{86}$ The Member State will have to submit a restructuring plan within two months of approval of the emergency aid. Any liquidity support and guarantees on liabilities is limited to banks with no capital shortfall and can be approved by the Commission for a maximum period of six months.

Although deposit guarantee funds to reimburse depositors do not constitute State aid, the use of those or similar funds to assist in the restructuring of credit institutions may

84 Andrew G. Haldane, 'Small Lessons from a Big Crisis', Paper presented at Federal Reserve Bank of Chicago 45th Annual Conference on Reforming Financial Regulation, 8 May 2009; and Kapsis 2012.

85 Banking Communication, paras 41-42. Subordinated creditors should not receive less in economic terms than what their instrument would be worth if no State aid were granted.

86 See para. 50 of Banking Communication:

If a Member State invokes this financial stability clause, the Commission will request an ex ante analysis from the competent supervisory authority confirming that a current (not prospective) capital shortfall exists, which would force the supervisor to withdraw the institution's banking license immediately if no such measures were taken. Moreover, any such analysis will have to demonstrate that the exceptional risk to financial stability cannot be averted with private capital within a sufficiently short period of time or by any other less distorting temporary measure such as a State guarantee. 
constitute State aid. The Commission adds that although the funds may derive from the private sector they may constitute aid if they are under the control of the State and the decision to provide these funds belongs to the State. On this basis, the Single Resolution Fund (the SRF), ${ }^{87}$ envisaged by the SRM, may be considered State aid under the TFEU. The Member State will raise contributions at national level from the institutions in order to establish a financial arrangement for resolution purposes. In practice, the use of the financing arrangement will be used to guarantee the assets or liabilities of the institution under resolution, to make loans to the institution under resolution, and to purchase assets of the institution under resolution. ${ }^{88}$

The Communication further adds that Member States must provide a plan for the orderly liquidation of the credit institution illustrating that the 'aid enables the credit institution to be effectively wound up in an orderly fashion, while limiting the amount of aid to the minimum necessary to keep it afloat during the liquidation in view of the objective pursued and complying with the burden-sharing requirements of this Communication' ${ }^{89}$ The institution must not compete on the market or pursue any new activities. ${ }^{90}$ In addition, any sale of a credit institution during an orderly liquidation procedure may entail State aid to the buyer, unless the sale is organized under the 'arm's-length' principle. If the sale is deemed to be State aid then this will be assessed by the Commission in accordance with the Communication.

\section{CONCLUSION}

This chapter analysed the special nature of banks, and how the importance of the banking sector and its stability overlaps with the preservation of competitive banking markets. State aid measures that characterized the response of regulators in the recent financial crisis were based on the premise of the special nature of the banking sector and its importance to the economy. In addressing the special nature of banks the chapter looked into the approach adopted towards banks under State aid control, tackling issues such as 'toobig-to-fail' and the BRRD and SRM.

87 The SRF was established according to Regulation (EU) No 806/2014 as a single financing arrangement for all Member States participating in the SSM and SRM. The Fund was foreseen as a common financial backstop. See Council Implementing Regulation (EU) 2015/81 of 19 December 2014 specifying uniform conditions of application of Regulation (EU) No 806/2014 of the European Parliament and of the Council with regard to ex ante contributions to the Single Resolution Fund [2015] OJ L15/1.

${ }_{88}$ Gianni Lo Schiavo, 'The Development of a New Bank Resolution Regime in Europe: Fit for Purpose?' (2014) 29(11) JIBLR 689 (Lo Schiavo 2014).

89 Banking Communication, para. 72.

90 The Commission states that:

Member States must submit regular reports (on at least a yearly basis) on the development of the liquidation process of each bank in liquidation and a final report at the end of the winding-up procedure. In certain cases, a monitoring trustee, a divestment trustee or both may be appointed to ensure compliance with any conditions and obligations underpinning the authorisation of the aid.

See further Banking Communication, para. 88 . 
Banks and other providers of finance normally play a crucial role in enhancing efficiency in markets; if the credit market ceases to function effectively, the whole economy will struggle to grow. It has been suggested that the emergence of 'too-big-to-fail' banks should be discouraged but not banned..$^{91}$ The reason is that they need to be rescued in order to avoid the systemic implications of their failure. However, the Commission has approved State aid measures under Article 107(3)(b) TFEU for banks that are not obviously 'too-big-to-fail'. ${ }^{92}$ During the crisis, on virtually no occasion did the Commission find aid to be incompatible with the internal market. ${ }^{93}$ Kokkoris and Marsden claimed that the approach of the Commission was a whitewash, which is supported by the argument that few cases were appealed. ${ }^{94,95}$

At the peak of the crisis and in its aftermath, it has been argued that there is a trade-off between competition and financial stability. ${ }^{96}$ Financial entities in distress have incentives to incur excessive risks and must be restrained in this tendency. Concerns over the extent to which antitrust policy should be flexible in support of other objectives are important and likely to have wide ramifications given the subsequent increase of governmental intervention in financial markets. As we saw in this chapter, there is no concrete correlation between banking stability and competition enforcement, and any arguments to the contrary risk creating anti-competitive banking markets.

91 Psaroudakis 2012.

92 Commission Letter NN39/2008 Roskilde Bank C (2008) 6498 [74]; Commission Letter NN23/2009 Fionia Bank C(2009) 4027.

93 Commission Decision on the State aid C33/2009, Banco Privado Português [2009] OJ C174/1; Commission Decision on the State aid SA.39451 (2015/C) implemented by Italy for Banca Tercas (not yet published).

94 Case T-457/09 Westfälisch-Lippischer Sparkassen- und Giroverband v Commission [2014] ECR I-000; Case T-29/10 Netherlands and ING Groep v Commission [2012] ECR I-000; Case T-319/11 ABN Amro Group NV v European Commission [2014] ECR I-000; Case T-487/11 Banco Privado Português, SA and Massa Insolvente do Banco Privado Português, SA v European Commission [2014] ECR I-000. See further Psaroudakis, 2012, who argues that the appeal cases have been brought by the aid recipients themselves complaining about the commitments imposed upon them.

95 Philip Marsden and Ioannis Kokkoris 'The Role of Competition and State Aid Policy in Financial and Monetary Law' in Rosa Lastra, Thomas Cottier and John Jackson, International Law in Financial Regulation and Monetary Affairs (OUP 2012).

96 Summary Record of the discussion on Competition and Financial Markets, DAF/ COMP/M(2009)1/ANN4, 10 April 2009, Roundtable 3 on Real Economy and Competition Policy in a Period of Retrenchment < www.oecd.org> accessed 27 April 2016. 